\title{
Laminin-Mediated Interactions in Thymocyte Migration and Development
}

\author{
Wilson Savino*, Daniella Arêas Mendes-da-Cruz, Daiane Cristina Ferreira Golbert, \\ Ingo Riederer and Vinicius Cotta-de-Almeida
}

Laboratory on Thymus Research, Oswaldo Cruz Institute, Oswaldo Cruz Foundation, Rio de Janeiro, Brazil

Intrathymic T-cell differentiation is a key process for the development and maintenance of cell-mediated immunity, and occurs concomitantly to highly regulated migratory events. We have proposed a multivectorial model for describing intrathymic thymocyte migration. One of the individual vectors comprises interactions mediated by laminins (LMs), a heterotrimeric protein family of the extracellular matrix. Several LMs are expressed in the thymus, being produced by microenvironmental cells, particularly thymic epithelial cells (TECs). Also, thymocytes and epithelial cells express integrin-type LM receptors. Functionally, it has been reported that the $d y / d y$ mutant mouse (lacking the LM isoform 211) exhibits defective thymocyte differentiation. Several data show haptotactic effects of LMs upon thymocytes, as well as their adhesion on TECs; both effects being prevented by anti-LM or anti-LM receptor antibodies. Interestingly, LM synergizes with chemokines to enhance thymocyte migration, whereas classe-3 semaphorins and B ephrins, which exhibit chemorepulsive effects in the thymus, downregulate LM-mediated migratory responses of thymocytes. More recently, we showed that knocking down the ITGA6 gene (which encodes the $\alpha 6$ integrin chain of LM receptors) in human TECs modulates a large number of cell migration-related genes and results in changes of adhesion pattern of thymocytes onto the thymic epithelium. Overall, LM-mediated interactions can be placed at the cross-road of the multivectorial process of thymocyte migration, with a direct influence per se, as well as by modulating other molecular interactions associated with the intrathymic-trafficking events.

Keywords: thymus, T-cell development, T-cell migration, thymic epithelial cells, extracellular matrix, laminin isoforms, integrins, chemokines

\section{INTRODUCTION}

The thymus plays a central role on the immune system, as the primary lymphoid organ where T lymphopoiesis takes place $(1,2)$. It is responsible for generating lymphocytes that exhibit a diverse group cells expressing the T-cell receptor (TCR), including the conventional $\mathrm{CD} 4^{+}$and $\mathrm{CD} 8^{+} \mathrm{TCR} \alpha \beta$ $\mathrm{T}$ cells, TCR $\gamma \delta \mathrm{T}$ cells, Foxp $3^{+}$regulatory T cells, and the invariant NK T cells (3). Along with this whole process, the thymus stems a complex set of differentiating signals that target bone marrowderived lymphoid progenitors which settle the thymus to become committed to T-cell lineage and further originating those distinct T-cell lineages (4). In this context, intrathymic T-cell differentiation is considered a key process for the development and maintenance of cell-mediated immune responses. 
Accordingly, bone marrow-derived T-cell precursors enter the thymus where they undergo a complex series of biological events, so that around $95 \%$ of the cells generated within the organ die by apoptosis. Meanwhile, a small proportion of cells is rescued from programed cell death and acquires the ability to exit the organ, ultimately reaching the thymus-dependent areas of the secondary lymphoid organs Figure 1A [reviewed in Ref. (5-7)]. These mature $\mathrm{T}$ cells are then able to mount a cell-mediated immune response.

The developmental journey that generates the conventional $\mathrm{CD}^{+}$and $\mathrm{CD}^{+} \alpha \beta \mathrm{T}$ cells has been extensively studied and involves a series of ordered proliferative and selective events, under the central influence of gene recombination at the TCR loci, that results in pre-TCR and $\alpha \beta$ TCR assembling (8). The pathway starts after progenitor cells enter the thymus at the socalled corticomedullary junction and migrate from the cortex in the direction to the subcapsular area as cells lacking CD4 and $\mathrm{CD} 8$ coreceptors, defined as double-negative (DN; CD4 ${ }^{-} \mathrm{CD} 8^{-}$) thymocytes. Here, the TCR rearrangement is tested through the expression of a pre-TCR, in a process called $\beta$-selection (9). Following the TCR $\alpha$ chain assembly at the highly expanded double-positive (DP; $\mathrm{CD} 4^{+} \mathrm{CD} 8^{+}$) stage, TCR specificity is tested in a process known as positive selection, where low-avidity interactions with self peptide-MHC complexes expressed on thymic epithelial cells (TECs) allow survival and further differentiation $(10,11)$. The differentiating DP thymocytes start to lose the expression of either CD4 or CD8 and migrate from the cortex toward the thymic medulla. The pathways leading to CD4 or CD8 SP subsets are dependent on distinct transcriptional machineries, seem to initiate at the transitional stage characterized as
$\mathrm{CD} 4^{+} \mathrm{CD} 8^{\text {lo }}$, and depend on the TCR interaction with MHC class II or class I [reviewed in Ref. (12-14)].

The most critical developmental cues arise from the tissue microenvironment. In this context, thymic microenvironmental cells - comprising cortical and medullary TECs as well as other stromal cells of mesodermal origin - provide the milieu for T-cell development and the final selection of a proper set of the T-cell repertoire (15).

The microenvironmental signals include cell surface and soluble molecules, such as Delta-class Notch ligand Delta-like 4 (Dll4), kit ligand, MHC molecules, and interleukin-7 (IL-7). Likewise, as intrathymic T-cell differentiation occurs concomitantly to highly regulated migratory events, chemokine-derived signals are present from the progenitor entrance until the exit of mature SP cells for the periphery $(7,16,17)$. In fact, as discussed below, we have proposed a multivectorial model for describing intrathymic migration of developing thymocytes (18). In this context, interactions with the extracellular matrix (ECM) also critically operate throughout the intrathymic T-cell maturational pathway (19).

Thymic epithelial cells are the major cellular component of the thymic microenvironment and are located in both the cortex (cTEC) and medulla (mTEC) of the thymic lobules. A special lymphoepithelial complex named thymic nurse cells (TNC) is located in the outer cortex and can be used as an in vitro model to study thymocyte migration in a tridimensional TEC context (16). In the medulla, a particular mTEC component is able to express the transcription factor autoimmune regulator which controls the thymic expression of so-called tissue-specific
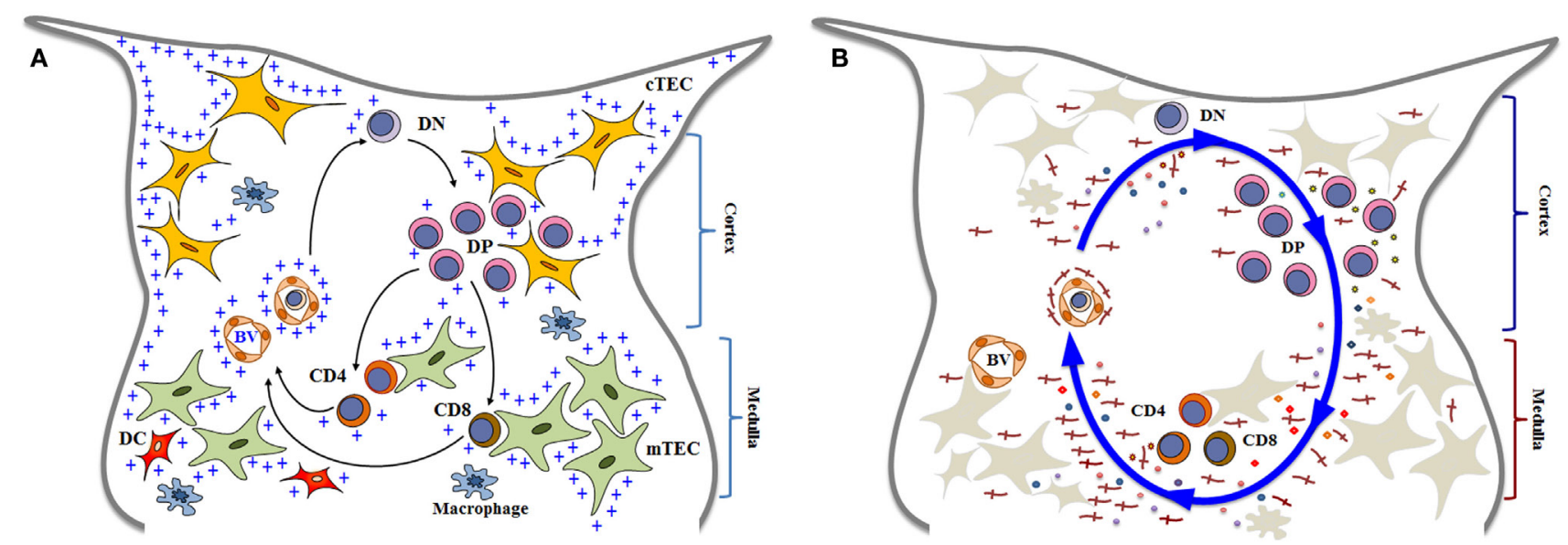

FIGURE 1 | Simplified diagrams of thymocyte differentiation and migration, in the context of the thymic microenvironment, according to a multivectorial migratory pattern. In (A), we show that bone marrow-derived T-cell precursors enter the thymus through blood vessels (BV) in the corticomedullary junction of thymic lobules. CD4-CD8- double negative (DN) immature thymocytes then migrate to the outer cortex, where they interact with cortical thymic epithelial cells (cTEC) and differentiate into $\mathrm{CD} 4{ }^{+} \mathrm{CD} 8^{+}$double positive (DP) cells. These cortical thymocytes will be able to continue to interact with microenvironmental cells as they migrate to the medulla, and positively selected cells will become either CD4 single-positive (CD4 SP) or CD8 single-positive (CD8 SP) cells, by interacting with medullary TEC (mTEC) or dendritic cells (DC) the medulla. In addition to cell-cell interactions between thymocytes and the microenvironmental components, developing thymocytes can be influenced by components of the extracellular matrix (herein labeled with blue crosses). Mature SP thymocytes will leave the organ by entering blood vessels that will allow them to find the way to colonize the T-cell-dependent zones of peripheral lymphoid organs. Although not showed in the cartoon, most thymocytes actually die and are rapidly phagocytized by macrophages. In (B), we illustrate that thymocyte migration occurs as a result of multiple interactions, following a multivectorial pattern throughout the thymic lobule. In this panel, we emphasize the importance of LM (the red crosses) as one vector involved in thymocyte migration, comprising both immature and mature cells. Diagrams modified from Ref. (16, 18, 81, 128, 129). 
antigens, and this interaction is important for avoiding autoimmunity $(20,21)$.

As seen below, microenvironmental cells are responsible to produce the ECM network in the thymus, as well as other cell migration-related moieties, such as chemokines $(16,19)$.

In this review, we specifically highlight the role of laminin (LM) isoforms for intrathymic T-cell migration and maturation in both physiological and pathological conditions.

\section{INTRATHYMIC EXPRESSION OF LM ISOFORMS AND INTEGRIN-TYPE LM RECEPTORS}

Laminins correspond to a family of heterotrimeric ECM proteins formed by an $\alpha, \beta$ and $\gamma$ chain; each being encoded by a specific gene. Several LM isoforms have been described and are classified according to the corresponding $\alpha, \beta$, and $\gamma$ chains. Once synthesized, the chains form a cross-shaped coiled-coil structure. Currently, five $\alpha$, three $\beta$, and three $\gamma$ chains have been chemically characterized, and 18 isoforms reported (see Table 1). The current nomenclature uses Arabic numerals based on the three chain numbers. For example LM- 111 is formed by $\alpha 1, \beta 1$, and $\gamma 1$ chains, whereas LM-211 is composed by $\alpha 2, \beta 1$, and $\gamma 1$ chains (22-24).

Laminin-mediated interactions are triggered by two main classes of receptors, integrin- and non-integrin-type receptors

TABLE 1 | Laminin isoforms and corresponding integrin-type laminin receptors ${ }^{\mathrm{a}}$.

\begin{tabular}{|c|c|c|c|}
\hline \multicolumn{2}{|c|}{ Laminin isoforms } & \multirow{2}{*}{$\begin{array}{l}\text { Composition } \\
\text { ( } \alpha, \beta, \text { and } \gamma \\
\text { chains) }\end{array}$} & \multirow{2}{*}{$\begin{array}{l}\text { Preferential integrin } \\
\text { receptors }\end{array}$} \\
\hline $\begin{array}{l}\text { Present } \\
\text { nomenclature }\end{array}$ & $\begin{array}{l}\text { Previous } \\
\text { nomenclature }\end{array}$ & & \\
\hline LM-111 & Laminin-1 & $\alpha 1 \beta 1 \gamma 1$ & $\begin{array}{l}\alpha 1 \beta 1, \alpha 2 \beta 1, \alpha 3 \beta 1 \\
\alpha 6 \beta 1, \alpha 6 \beta 4, \text { and } \alpha 7 \beta 1\end{array}$ \\
\hline LM-121 & Laminin-3 & $\alpha 1 \beta 2 \gamma 1$ & $\alpha 6 \beta 1, \alpha 6 \beta 4$, and $\alpha 7 \beta 1$ \\
\hline LM-211 & $\begin{array}{l}\text { Laminin-2/ } \\
\text { merosin }\end{array}$ & $\alpha 2 \beta 1 \gamma 1$ & $\begin{array}{l}\alpha 6 \beta 1, \alpha 3 \beta 1, \alpha 6 \beta 4, \\
\text { and } \alpha 7 \beta 1\end{array}$ \\
\hline LM-212 & - & $\alpha 2 \beta 1 \gamma 2$ & $\alpha 3 \beta 1, \alpha 6 \beta 1$, and $\alpha 7 \beta 1$ \\
\hline LM-222 & - & $\alpha 2 \beta 2 \gamma 2$ & $\alpha 3 \beta 1, \alpha 6 \beta 1$, and $\alpha 7 \beta 1$ \\
\hline LM-213 & Laminin-12 & $\alpha 2 \beta 1 \gamma 3$ & - \\
\hline LM-221 & Laminin-4 & $\alpha 2 \beta 2 \gamma 1$ & $\alpha 7 \beta 1$ \\
\hline LM-311 & $\begin{array}{l}\text { Laminin-6/ } \\
\text { Laminin-6A }\end{array}$ & $\alpha 3 \beta 1 \gamma 1$ & $\alpha 3 \beta 1$ and $\alpha 6 \beta 1$ \\
\hline LM-321 & $\begin{array}{l}\text { Laminin-7/ } \\
\text { laminin-7A }\end{array}$ & $\alpha 3 \beta 2 \gamma 1$ & ND \\
\hline LM-323 & Laminin-13 & $\alpha 3 \beta 2 \gamma 3$ & - \\
\hline LM-332 & Laminin-5 & $\alpha 3 \mathrm{~B} \beta 2 \gamma 1$ & $\begin{array}{l}\alpha 1 \beta 1, \alpha 3 \beta 1, \alpha 6 \beta 1 \\
\text { and } \alpha 6 \beta 4\end{array}$ \\
\hline LM-411 & Laminin-8 & $\alpha 4 \beta 1 \gamma 1$ & $\alpha 3 \beta 1, \alpha 6 \beta 1$, and $\alpha 7 \beta 1$ \\
\hline LM-421 & Laminin-9 & $\alpha 4 \beta 2 \gamma 1$ & $\alpha 6 \beta 1$ \\
\hline LM-423 & Laminin-14 & $\alpha 4 \beta 2 \gamma 3$ & - \\
\hline LM-511 & Laminin-10 & $\alpha 5 \beta 1 \gamma 1$ & $\alpha 3 \beta 1, \alpha 6 \beta 1$, and $\alpha 6 \beta 4$ \\
\hline LM-521 & Laminin-11 & $\alpha 5 \beta 2 \gamma 1$ & $\alpha 3 \beta 1, \alpha 6 \beta 1$, and $\alpha 6 \beta 4$ \\
\hline LM-522 & - & $\alpha 5 \beta 2 \gamma 2$ & $\alpha 3 \beta 1$ \\
\hline LM-523 & Laminin-15 & $\alpha 5 \beta 2 \gamma 3$ & - \\
\hline
\end{tabular}

${ }^{a}$ Data adapted from Ref. (25-40).

$N D$, not determined; - absence of integrin binding because of the $\gamma 3$ chain of the LM isoform (27).
(41, 42). At least eleven integrins, namely $\alpha 1 \beta 1, \alpha 2 \beta 1, \alpha 2 \beta 2$, $\alpha 3 \beta 1, \alpha 6 \beta 1, \alpha 6 \beta 4, \alpha 7 \beta 1, \alpha 9 \beta 1, \alpha v \beta 3, \alpha v \beta 5, \alpha v \beta 8$, and $\alpha M \beta 2$, can bind to LMs $(25,43-49)$. Moreover, there is, to some extent, a specificity of given integrins to bind different LMs. For example, the integrins $\alpha 6 \beta 1$ and $\alpha 3 \beta 1$ (CD49f/CD29 and CD49c/CD29, respectively) recognize both LM-511 and LM-521 (26). A second integrin bearing the $\alpha 6$ subunit, the $\alpha 6 \beta 4$ LM receptor (CD49f/ CD104), presents the highest affinity for LM-3A32 (26).

Upon LM, binding integrins acts through outside-in signaling, promoting modulation in phosphorylation states and activities of cytosolic tyrosine kinases, such as focal adhesion kinase and Src family kinases, which subsequently regulate other kinases, scaffolding proteins, and intracellular signal transduction $(50,51)$. Such signaling is initially triggered by the binding of the globular domains of LM $\alpha$-chains to integrins (24). In this respect, LM isoforms containing the $\gamma 3$ chain are unable to bind to integrins due to the absence of the glutamic acid residue, which is conserved in the C-terminal regions of the $\gamma 1$ and $\gamma 2$ chains (27).

The list of LM isoforms and corresponding integrin-type receptors so far described is summarized in Table 1, and the general gene and protein features, as well as functions in the hemopoietic system can be fully accessed at the LM Database Version 2.0: www.lm.lncc.br (28).

Laminins are heterogeneously distributed within the thymic lobules. The initial immunolocalization studies, using anti-LM polyclonal antibodies that do not discriminate a specific LM isoform, revealed a heterogeneous distribution, with the medulla containing a denser LM network as compared to the cortex (52). Additionally, perivascular spaces (PVS) as well as periseptal basement membranes contain LM. This distribution pattern is observed in both human and mouse thymuses (52-54). Moreover, in vitro studies revealed that TECs, as well as phagocytic cells of the thymic reticulum, are able to produce $\operatorname{LM}(52,53,55)$.

Gene expression analyses revealed that genes coding for several LM chains are constitutively expressed in the human thymus $(29,56,57)$. Moreover, taking advantage of the availability of antibodies able to specifically discriminate LM chains, isoforms could be more precisely located within the thymus.

Laminin-111 appears early and is the main LM isoform during embryogenesis (58-60). However, in adults, LM-111 expression is very limited, being detected in some epithelial basement membranes $(61,62)$. Interestingly, although PCR amplification from bulk thymus extracts did not reveal the $\alpha 1$ LM chain $(29,57)$, it was clearly identified in extracts obtained from cultured TEC or TNC (57). This result points to the possibility that particular culture conditions may modify the expression of LM chains. Moreover, In addition to its role in thymocyte migration (further discussed below), LM-111 is able to stimulate the proliferation both mouse and human TEC $(53,63)$.

Laminin-211 (formerly called merosin) is present in the basement membrane of the skeletal muscle (64) and also occurs in different organs, including the mouse and human thymus (29, 30, $57)$. The $\alpha 2 \mathrm{LM}$ chain is observed in the subcapsular epithelium and blood vessels of human thymus (29); being also detected in cultures of TEC and TNC complexes (57). In mice, immature thymocytes bind more to LM-211 when compared to mature ones, and use the $\alpha 6 \beta 1$ integrin, rather than $\alpha 6 \beta 4$ to adhere to this 
isoform (30). Human thymocytes express both $\alpha 6 \beta 1$ and $\alpha 3 \beta 1$ integrin-type LM receptors, which mediate the binding to this isoform and are involved in thymocyte proliferation triggered by a costimulatory signal from anti-CD3 antibody plus LM-211 (31). However, differently from these results, it has been reported that none of the thymocyte subpopulations bind to LM-211 or LM-221 (29). Such discrepancy may be due to different experimental conditions, or even the quality of the LM preparations.

However, in vivo data revealed that mice spontaneously lacking LM-211 $(d y / d y)$ show a disorganized and smaller thymus, with a reduced number of thymocytes, particularly in DP subpopulation. In these animals, capsular and subcapsular DN thymocytes exhibit increase in apoptosis (65). Using another $\alpha 2$ LM mutant mouse $(d y 3 k / d y 3 k)$, an apoptosis-related decrease in the DP subset was also reported. Furthermore, LM-211 increased the viability of normal thymocytes (66). Interestingly, the lack of LM-211 in the animals also compromises the functional innervation of the organ, since the acetylcholinesterase activity of the $d y / d y$ mouse thymus is decreased in $50 \%$ as compared to age/matched normal (67). Taken together, these data indicate a pleiotropic effect of LM-211 upon the thymus.

Studies on the distribution of LM-332, using reagents able to define the localization of $\alpha 3, \beta 3$, and $\gamma 2$ LM chains, revealed that such isoform is present in the medullary area of the thymic parenchyma and the basal laminae of the subcapsular cortex and of blood vessels. More precisely, LM-332 was localized in epithelial cells (defined by keratin staining) and surrounding blood vessels, including capillaries $(29,56)$. Three-dimensional reconstruction of human thymic lobules, using confocal microscopy after immunohistochemical staining revealed a sort of LM-332containing conduit structure surrounded by TECs in the medulla of the thymic lobules. In these conduits, immunohistochemistry staining with polyclonal antibodies for LM from EngelbrethHolm-Swarm murine sarcoma basement membrane, which do not recognize LM-332, indicates that other LM isoforms can be present. Indeed, TEC primary cultures, but not thymic dendritic cells that also surround the conduits, express the LM chains containing the isoform 332. Measurements of these structures revealed that they are too narrow to allow a flow of cells, thus raising the hypothesis that they provide an influx of molecules in the thymic medulla (68). Yet, experimental evidence to prove this possibility remains to be obtained.

Functionally, it has been shown that soluble LM-332 inhibits human thymocyte proliferation induced by anti-CD3 plus IL-2 (56). In another work, CD8 ${ }^{+}$SP thymocytes were the only subpopulation able to adhere onto LM-332, being this adhesion dependent of $\alpha 6 \beta 4$ integrin (29). These results indicate that this isoform can be involved in the differentiation of the more mature subpopulations from the thymus. Interestingly, this is in opposite to the LM containing the $\alpha 2$ chain, which are located in the subcapsular region and functionally seems to affect more immature subpopulations.

Gene expression for $\alpha 3, \beta 3$, and $\gamma 2$ LM chains (which form LM-332) was also detected in the mouse thymus. Nevertheless, at variance with the pattern reported for humans, in the mouse thymus, in situ hybridization together with immunohistochemical studies revealed a more restricted distribution of this LM isoform, only in the outer cortex of the thymic lobules (69). The discrepancies concerning LM-332 distribution in the thymus of these species remain to be elucidated. They can be real biological differences, or they can derive from differences in the reagents applied. In any case, using anti-LM-332 blocking antibodies in fetal thymus organ cultures, the authors found an arrest in T-cell development at the DN stage of differentiation, thus unraveling the role of this isoform in thymus physiology (69).

Laminin isoforms containing $\alpha 4$ and $\alpha 5$ chains are the main isoforms found in the basal membranes of the endothelium (70). Accordingly, in the human thymus, $\alpha 4$ LM chain is restricted to the endothelium, as defined by anti-PECAM staining, with the isoforms 411 and 421 present in the blood vessels (29). However, PCR analysis of TEC and TNC bulk extracts in culture suggests the presence of LM containing the $\alpha 4$ chain (57), also indicating that particular culture conditions may modify the expression of LM chains.

Laminin-511 is widely distributed in the body and, in the basement membrane of the blood vessels, LM-511 and LM-521 are normally associated with the isoform 411 (70). In the thymus, the $\alpha 5$ LM chain was observed in the subcapsular epithelium of the thymic lobules and in the thymic blood vessels, together with LM-411. Functionally, in vitro experiments showed that the thymocytes binding to LM-511 was mediated by the integrin $\alpha 6 \beta 1$, with a preferential adhesion of DN thymocytes to LM-511/ LM-521 (29).

If in one hand LM isoforms containing the $\alpha 2, \alpha 4$, and $\alpha 5$ chains can be detected in thymic blood vessels, the expression of the isoform LM-332 (containing the $\alpha 3$ and $\gamma 2$ chains) seems to be a main feature of $\operatorname{mTEC}(29,56)$. It is thus conceivable that distinct LM isoforms play specific roles in the intrathymic T-cell differentiation and migration.

Overall, the RT-PCR analysis of human LM isoform gene expression together with immunohistochemical data on tissue sections and cultured TEC and TNC showed that genes coding for LM components are actively transcribed both in situ and in TEC cultures, and actually the corresponding polypeptides are assembled to form the respective isoforms $(29,56,57)$. It is important to mention that the studies employing PCR from thymus bulk extracts suggest the presence of LM-211, LM-332, LM-411, and LM-511, which are already described in situ, using specific antibodies for the LM chains (see Table 2). Additionally,

\begin{tabular}{|c|c|c|c|c|}
\hline $\begin{array}{l}\text { Laminin } \\
\text { isoforms }^{b}\end{array}$ & $\begin{array}{l}\text { Subcapsular } \\
\text { cortex }\end{array}$ & $\begin{array}{l}\text { Inner } \\
\text { cortex }\end{array}$ & Medulla & Perivascular \\
\hline LM-211 & + & - & - & + \\
\hline LM-221 & + & - & - & + \\
\hline LM-332 & + & - & + & - \\
\hline LM-411 & - & - & - & + \\
\hline LM-421 & - & - & - & + \\
\hline LM-511 & + & - & - & + \\
\hline LM-521 & + & - & - & + \\
\hline
\end{tabular}

${ }^{a}$ Data compiled from Ref. $(29,31,55,56,68,69)$.

${ }^{b}$ We did not find any published report concerning the intrathymic localization of other LM isoforms, despite some LM chains were detected in thymic bulk extracts. 
TABLE 3 | Expression of integrin-type laminin receptors by developing thymocytes and thymic microenvironmental cells ${ }^{\text {. }}$

\begin{tabular}{|c|c|c|c|c|c|c|c|}
\hline \multirow[t]{2}{*}{ Laminin receptor ${ }^{\mathrm{b}}$} & \multicolumn{4}{|c|}{ CD4/CD8-defined developing thymocytes ${ }^{c}$} & \multicolumn{3}{|c|}{ Thymic microenvironmental cells } \\
\hline & DN & DP & CD4 SP & CD8 SP & TEC & TDC & Endo \\
\hline$\alpha 1 \beta 1$ & - & - & - & - & + & ND & + \\
\hline$\alpha 2 \beta 1$ & - & - & - & - & + & + & + \\
\hline$\alpha 2 \beta 2$ & ND & ND & ND & ND & + & ND & ND \\
\hline$\alpha 3 \beta 1$ & + & - & + & + & + & ND & + \\
\hline$\alpha 6 \beta 1$ & + & + & + & + & + & ND & ND \\
\hline$\alpha 6 \beta 4$ & + & - & + & + & + & ND & ND \\
\hline$\alpha 7 \beta 1$ & ND & ND & ND & ND & + & ND & ND \\
\hline
\end{tabular}

${ }^{a}$ Data compiled from Ref. (63, 71-75).

${ }^{b}$ We did not find any published report concerning the intrathymic expression of the following laminin-binding integrins: $\alpha 9 \beta 1, \alpha v \beta 3, \alpha v \beta 5, \alpha v \beta 8$, and $\alpha M \beta 2$.

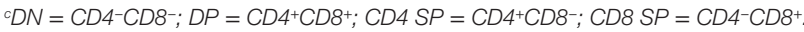

TEC, thymic epithelial cell; TDC, thymic dendritic cell; Endo, endothelium; ND, not determined.

these works suggest the presence of LM-311 and $\gamma 3$-containing LM isoforms $(29,57)$. Yet, these studies are essentially based on the thymus sections from infants, and the knowledge on fetal as well as aging thymus has not been settled yet.

Among the various integrin-type LM receptors described in the thymus, VLA- 6 ( $\alpha 6 \beta 1$ or CD49f/CD29) is the most studied; being expressed by developing thymocytes, in their various CD4/ CD8-defined subsets, as well as thymic microenvironmental cells, particular TEC. Nevertheless other LM receptors, such as $\alpha 3 \beta 1$ and $\alpha 6 \beta 4$, are also constitutively expressed by developing thymocytes and TEC $(30,57,63,71)$.

The intrathymic distribution of LM isoforms in normal conditions is summarized in Table 2, whereas the expression of some integrin-type LM receptors by thymic cells is seen in Table 3.

\section{ROLE OF LMS IN THYMOCYTE MIGRATION}

\section{LM-Mediated Interactions as a Vector Influencing Thymocyte Migration}

Migration within a solid tissue requires transient adhesion of migrating cells on the cellular and ECM substrates. Accordingly, adhesion assays, as well as migration assays using transwell migration chambers have been extensively used to test whether LMs are involved in thymocyte migration. Moreover, we have used TNC to study migration of developing thymocytes in the context of the tridimensional structure of these lymphoepithelial complexes (76). TNC can be isolated from the thymus of various species and contain one TEC that harbor a variable number of thymocytes, mostly immature DP cells. These complexes can be settled in culture, where they progressively release thymocytes. Additionally, TNC-derived epithelial cells can be let in contact with immature thymocytes and re-form the classical TNC lymphoepithelial structures. Accordingly, evaluation of thymocyte release and reconstitution of TNC complexes may be applied to approach the exit and entrance of thymocytes in the epithelial niche.

We have showed that thymocyte adhesion onto TEC monolayers is partially mediated by LM/VLA-6 interactions, being largely impaired in the presence of anti-CD49f monoclonal antibodies (63). Furthermore, when we treated mouse or human
TEC with different stimuli that enhance LM production and LM receptor expression, we found an increase of thymocyte adhesion; an effect that could be prevented by anti-LM or antiCD49f antibodies $(63,77-79)$. This interaction is also blocked by monoclonal antibodies specific for integrin $\alpha 6 \beta 1$ and its LM ligand LM-211 (57). This is similar to the previous studies performed in the mouse thymus showing that the thymocyte adhesion onto LM-211 could be abrogated by anti-CD49f or anti-CD29 antibodies (recognizing $\alpha 6$ and $\beta 1$ integrin chains, respectively) (30). LM-111 as well as LM-211 can also modulate thymocyte trafficking in TNC complexes, stimulating both the entrance and exit of thymocytes in cultures of the TNC lymphoepithelial complexes, and such migratory patterns could be blocked with anti-CD49f antibodies recognizing $\alpha 6$ integrin chain $(19,63,77)$.

We have proposed a model termed multivectorial thymocyte migration. Accordingly, a vector represents, as in Physics, a force that has magnitude and direction (and can be associated to other vectors) acting upon an object. In this sense, the oriented movement of developing thymocytes - resulting from cell velocity and displacement in a given moment and in a particular thymic zone - might be a resulting vector from individual migrating vectors, which represent the various ligand-receptor interactions that influence thymocyte migration $(18,80,81)$. This model can be seen in Figure 1B. Moreover, using ex vivo migration assays, we found that a given cell migration-related ligand/receptor pair interaction can modulate another pair (82-84), thus rendering the model still much more complex.

Laminin-mediated interactions can be placed as an individual vector in the multivectorial model (or group of vectors depending on each isoform), inducing thymocyte migration and consequently differentiation, contributing to the final resulting vector, alone or combined with other molecules, as we further discuss below. This is illustrated in Figure 1B.

It is well described that LM (in this case LM-111) induces mouse thymocyte haptotaxis in ex vivo assays using freshly isolated thymocytes $(18,82,83)$. Also, experiments using mouse LM-111 revealed that LM-mediated interactions are relevant for the entrance of T-cell precursors into the thymus $(19,85)$, for the migration of developing thymocytes, both in mice and humans $(57,68,86)$, as well as in peripheral lymphoid organs $(87,88)$. 
Data from mouse and human models revealed that LM-211 also exerts a haptotactic effect upon normal thymocyte migration, as revealed by ex vivo transmigration assays, as well as by in vitro thymocyte entrance and exit of TNC lymphoepithelial complexes. Again, this interaction is also blocked by monoclonal antibodies specific for integrin $\alpha 6 \beta 1$ and its LM ligand LM-211 (57). This is similar to the previous studies performed in the mouse thymus showing that the thymocyte adhesion onto LM-211 could be abrogated by anti-CD49f or anti-CD29 antibodies (30). Additionally, in the human model, it was showed that thymocyte adhesion can be impaired by anti- $\alpha 3$ integrin chain antibodies (57), strongly indicating that LM-211 can modulate thymus physiology by using at least two distinct LM-binding integrins.

More recently, we applied the RNA interference (RNAi) approach to study the role of integrin-type ECM receptors upon the thymic epithelium and the resulting interactions with developing thymocytes $(72,89)$. Modulation in both gene and protein expressions affecting LM-mediated interactions has been reported influencing thymocytes. For example, RNAi-induced knockdown of the ITGA6 gene in cultured human TEC induced a significant decrease in CD49f membrane expression, with consequent decrease in the adhesion of these cells to LM and to cultured TEC. Moreover, we found up- and downregulation of a large number of cell migration-related genes, including those encoding LM chains, integrin sub-unities, as well as chemokine and cytokines; some of them are illustrated in Figure 2 (72). In this case, genetic modulation provided important information on the regulatory relation between the $\alpha 6$ integrins and thymic epithelium adhesion and migration genes. These data clearly show that downregulation of ITGA6 gene in the human thymic epithelium triggers a complex cascade of effects upon the expression levels of several other cell migration-related genes, including ECM and chemokine ligands and receptors. Taken together, these data unravel the concept that the expression of genes involved in controlling of thymocyte migration by the thymic microenvironment should be regarded as complex networks, so that a defect in the expression of one single gene may reflect in an amplified cascade with functional consequences for TEC adhesion onto the natural ligand and potential consequences upon the normal patterns of TEC/thymocyte interactions.

\section{Other Cell Migration-Related Vectors Act Synergistically with LM on Thymocyte Migration}

One new interesting topic of study approaches the possibility that other factors could act synergistically with LM and significantly influence thymocyte migration. In this context, LM-111 can enhance the chemotactic activity of chemokines when both molecules are placed in combination in transmigration chambers. The CXCL12 chemokine per se also induces thymocyte migration, but when combined with LM a synergic migratory response can be observed in different thymocyte subpopulations, mainly the immature DP cells Figures 3A,B (90).

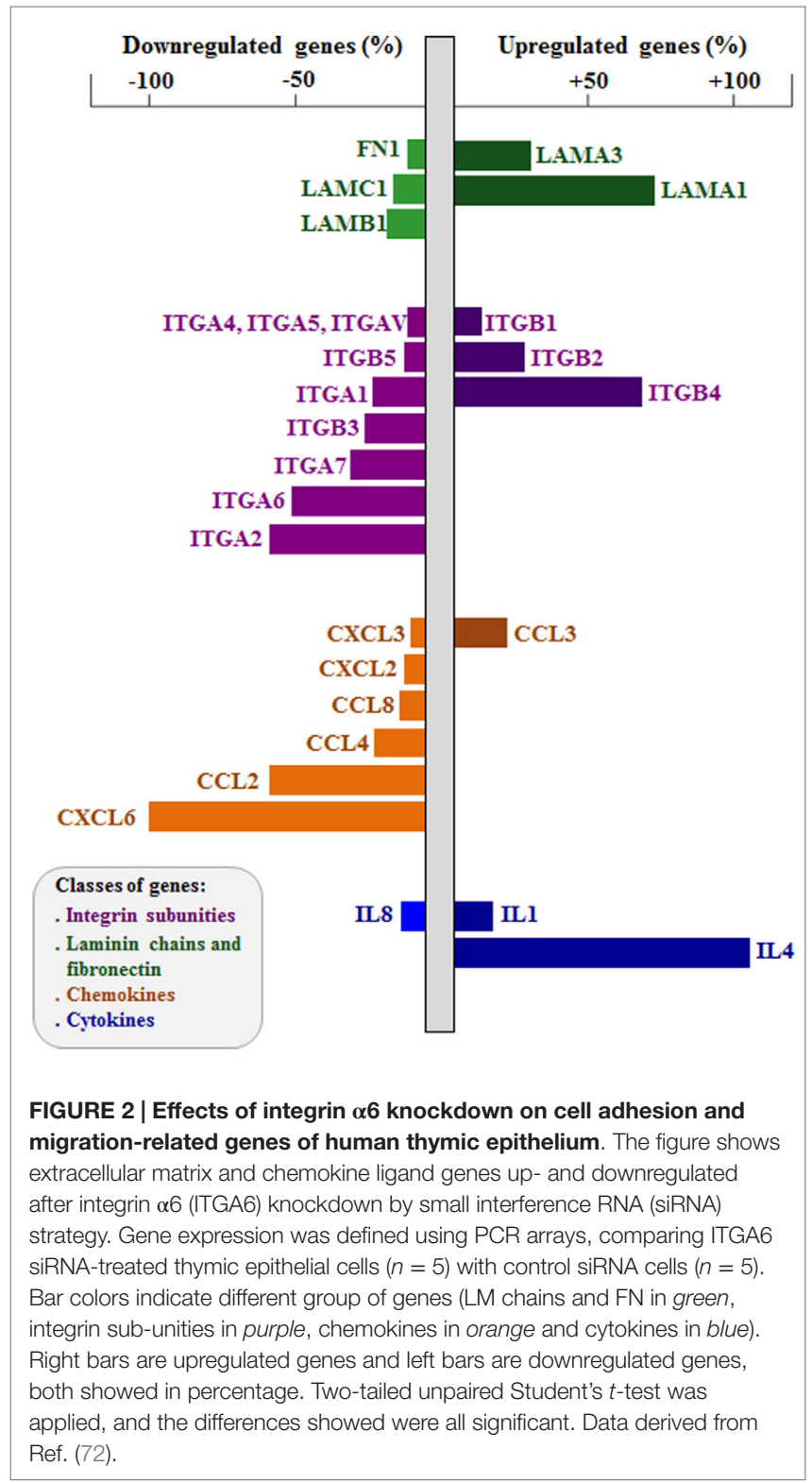

Interestingly, a synergic effect was also observed for LM combined with other chemokines as CCL22 and CCL19, but in this case the more responsive subpopulations were mature CD4 and CD8 SP thymocytes.

These observations suggest that LM can enhance responsiveness to chemokines but depending on the combination of molecules, the response is more evident in specific thymocyte subsets. Nevertheless, these effects were measured using LM-111, and so far we do not know whether other LM isoforms act similarly. Nevertheless, these data point to a possible bidirectional influence between a given migration vector and LM-mediated interaction upon thymocyte migration. Yet, further studies are warranted to mechanistically approach such a hypothesis. 


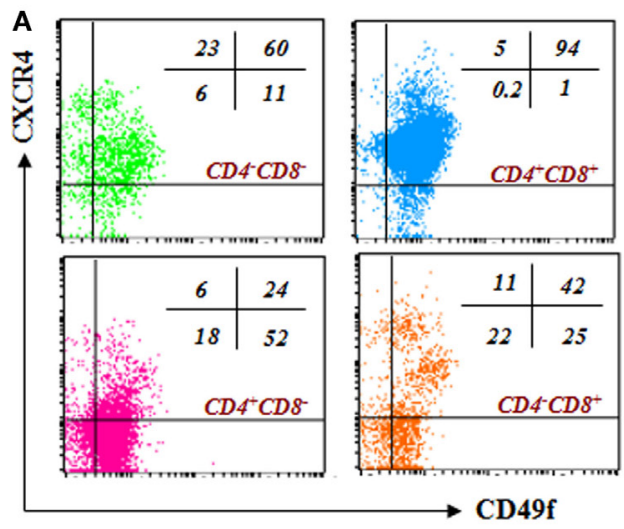

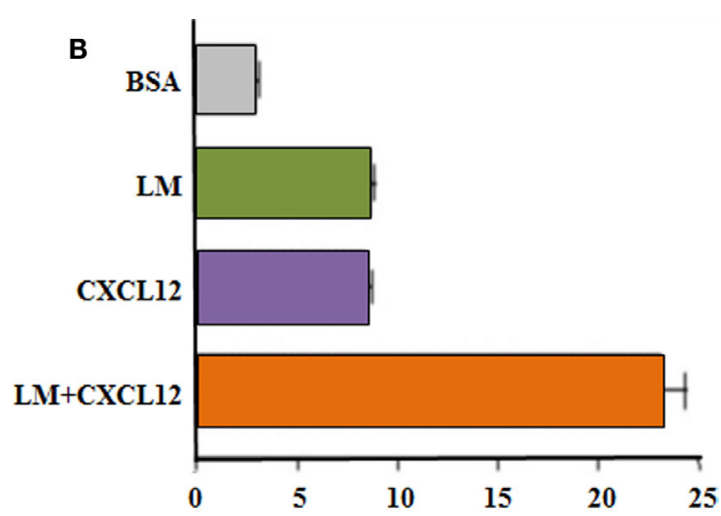

Absolute numbers of migrating thymocytes $\left(\mathrm{x} 10^{4}\right)$

FIGURE 3 | Laminin receptor expression and laminin-driven migration of mouse thymocytes: relationship with CXCL12/CXCR4 interactions. (A) depicts a dot plot derived from four-color cytofluorometric immunostaining of mouse thymocytes. The panel shows the simultaneous membrane expression of CD49f ( $\alpha 6$ integrin chain) and CXCR4, the CXCL12 chemokine receptor, in the four CD4/CD8-defined thymocyte subsets. In this panel, it is clear that in all immature and thymocyte thymocyte subpopulations, there are cells expressing both receptors. The numbers seen in each dot blot represent the percentages of cells expressing either CD49f and/or CXCR4 in each CD4/CD8-defined thymocyte subset. (B) reveals that thymocytes migrate toward CXCL12 and LM-111, as compared to bovine serum albumin (BSA), used as negative control. Interestingly, when migratory stimuli were applied simultaneously, the resulting migration was higher than the sum of each stimulus used alone, strongly indicating synergy between LM and CXCL12 to stimulate cell migration. Data derived from Ref. (19).

\section{Hormonal Control of LM-Mediated Thymocyte Migration}

Laminin and VLA-6 expression in the thymus can be upregulated by hormones such as the growth hormone $(\mathrm{GH})(88)$. We initially showed that GH treatment of human TEC enhances LM production, the expression of LM, with consequent increased adhesion of thymocytes to treated TEC, and also the release of thymocytes from TNC; effects that could be abrogated by anti-LM and anti-LM receptor antibodies (79). In vivo studies showed that thymocytes from $\mathrm{GH}$-transgenic mice, or from control mouse thymus injected with $\mathrm{GH}$, migrate more through LM, but not through fibronectin (FN), when comparing to controls $(82,91)$. The combination of LM with CXCL12 synergized migratory responses, and this phenomenon could be observed in all thymocyte subpopulations. Interestingly enough, treatment with pertussis toxin (which catalyzes Goi ADP-rybosilation, therefore resulting in signaling inhibition of $\mathrm{G}$ protein-coupled receptors, including chemokine receptors) prior to ex vivo migration assays blocked the migration of both control and GH-transgenic mouse thymocytes but did not change the profiles of LM-triggered thymocyte migration. However, when thymocytes from GH-transgenic mice were preincubated with anti-VLA-6-blocking $\mathrm{mAb}$ (that recognizes the CD49f chain) and then subjected to CXCL12 stimulation, a decrease in the numbers of migrating cells is observed (82). These results reinforce the idea of a crosstalk between integrins and chemokine receptors and the fact that the relative influence of VLA- 6 on the CXCR4 signaling pathway seems to be more relevant than the reverse situation.

Triiodothyronine (T3), a thyroid hormone critical for the regulation of body metabolism, growth, and development, also exerts several effects on thymus physiology. Mice treated with T3 exhibited an increase in thymus weight and cellularity and an enhancement in the intrathymic expression of ECM and ECM receptors on thymocytes, including LM and VLA-6, respectively
(92-94). Consequently, after short- and long-term T3 treatments, migration of thymocytes through LM is increased in ex vivo assays, proportionally to the treatment. Moreover, T3 stimulates thymocyte egress to peripheral lymphoid organs. Recent thymic emigrants (RTE) were evaluated by flow cytometry in the spleen, subcutaneous, and mesenteric lymph nodes $16 \mathrm{~h}$ after intrathymic FITC injection, and it was observed that T3 treatment changed the distribution of RTE among lymphoid organs, directing cells to lymph nodes instead of the spleen (95). These findings indicate that T3, by enhancing migratory capacity of thymocytes in response to LM, can redirect lymphocyte homing in the periphery.

Glucocorticoid (GC) hormones also regulate intrathymic LM-mediated interactions. Mice injected with GCs exhibit a rapid thymocyte depletion, which is paralleled by an enhancement of LM deposition within both cortical and medullary regions of the thymic lobules. Such an effect is not only due to the atrophy of the organ, since treating cultured TEC with dexamethasone also enhances LM production (52). Additionally, developing thymocytes from GC-treated mice exhibit a higher membrane expression of the CD49f chain of LM receptor (63). Moreover, GC treatment on cultured TEC enhances LM production, increases thymocyte adhesion, as well as the release of thymocytes from TNC complexes; effects that can be reversed by anti-CD49f antibody treatment (63). Overall, these data showed that GC is able to modulate cell migration-related LM-mediated interactions in the thymus. Nevertheless, it is to be determined if GC per se can directly induce thymocyte migration or act via the effect on TEC.

\section{OTHER MOLECULES CONTROLLING LM-MEDIATED MIGRATION}

The expression of some molecules initially described in the nervous system, such as neuropilins (NRPs) and ephrins, can also be observed in the thymus. Interestingly, these molecules were also 
shown to play a role in thymocyte migration and in modulating LM-induced haptotactic responses.

Neuropilins are transmembrane glycoprotein receptors for secreted class 3 semaphorins (Semas) and some vascular endothelial growth factor isoforms (96). Several NRP/Sema receptor/ ligand pairs are expressed in the mouse and human thymuses, in both lymphoid and non-lymphoid compartments (97). The expression patterns of NRPs and Semas, such as NRP1/Sema3A, suggests their involvement in numerous cell processes in the thymus, including thymocyte adhesion and migration. Sema3A treatment, for example, decreases the adhesion of human NRP1 ${ }^{+}$ thymocytes on TEC monolayers (83). Moreover, Sema3A exerts a dose-dependent chemorepulsive effect on human thymocytes, and it inhibits LM-induced thymocyte migration (83). Yet, this inhibitory effect is not restricted to LM, since Sema3 A treatment also abrogates FN or CXCL12-driven migration of all CD4/CD8defined thymocyte subsets (95).

Ephrins are also expressed in numerous cell types, including TEC and thymocytes, and bind the Eph receptor family, which corresponds to the largest family of tyrosine-kinase receptors in animal cells (98). In the thymus, it has been demonstrated that Eph/Ephrins signaling is relevant for cell migration, including the entry of bone marrow progenitor cells, migration of thymocytes within the organ and thymocyte export, triggered by chemokines and/or ECM proteins, including LM-111. Eph stimulation by ephrin B1 inhibits LM-111- and FN-driven migration responses as well as CXCL12-, CCL21-, and CCL25-induced chemotaxis of both bone marrow progenitors and thymocytes from normal mice $(81,85)$. The fact that LM-111 is involved in the entrance of T-cell precursors into the developing thymus is in keeping with previous data showing that anti-CD49f antibodies largely reduced the number of thymocytes in a mouse model of thymus colonization by T-cell precursors (99). Yet, we do not know whether other LM isoforms are biologically active in promoting these effects.

Noteworthy, the prion cellular protein $\left(\mathrm{PrP}^{\mathrm{C}}\right)$ can also be found in the nervous and immune systems and can bind LM through its $\gamma 1$ chain (100-103). In the thymus, $\operatorname{PrP}^{\mathrm{C}}$ is physiologically expressed by mouse thymocytes and TEC. Although $\operatorname{PrP}^{\mathrm{C}}$-deficient mice do not exhibit major changes in thymus physiology, $\operatorname{Pr}^{\mathrm{C}}$ overexpression has a major influence in thymocyte development, since $\operatorname{PrP}^{\mathrm{C}}$ transgenic mice show a severe thymic hypoplasia with thymocyte differentiation being largely blocked at immature stages (104). Moreover, the remaining immature thymocytes present impaired LM-driven migration, and this is paralleled by the fact that the number of $\mathrm{CD}^{+}$and $\mathrm{CD}^{+} \mathrm{T}$ cells in peripheral lymphoid organs is largely diminished (105). All together, these findings indicate that overexpression of $\operatorname{PrP}^{\mathrm{C}}$ generates a multifaceted disturbance in T-cell development, and change, at least via LM-driven interactions, the general migration pattern of developing thymocytes, including their export from the organ.

Despite not being shown to directly interact with LM in the thymus, other ECM associated molecules that mediate thymocyte interactions via integrin-type LM receptors have been reported. Recently, the LM-related molecule named netrin-1, also initially described in the nervous system, was found to be expressed in thymic stromal cells and also in anti-CD3- or IL-7-stimulated thymocytes (106). Additionally, in vitro assays demonstrated that thymocytes strongly adhere to netrin-coated surfaces, in a manner partially dependent on $\alpha 6 \beta 4$ integrin, and netrin was shown to potentiate CXCL12-driven chemotaxis of thymocytes (106).

Another matricellular protein called Cyr61/Ccn1, which binds $\alpha 6 \beta 1$ integrin (107), is produced by thymic microenvironmental cells (108), with TEC as the main source, and was shown to enhance both TEC proliferation and TEC-thymocyte interactions (109).

\section{Expression of LM and Its Possible Role on Thymocyte Migration in Disease Infectious Diseases}

In some pathological conditions, the expression/deposition of LM and LM receptors in the thymus can be modulated. These alterations can, in turn, alter thymocyte migration. This is the case of the Trypanosoma cruzi infection, the experimental model of Chagas disease. Thymuses from T. cruzi acutely infected mice present a severe atrophy, which is characterized by death of DP thymocytes by a caspase-dependent apoptosis mechanism (110-113). In parallel, we described a premature exit of immature DN and DP cells (which may have not been subjected to intrathymic selection processes) to peripheral lymphoid organs, and that persists in the chronic phase of Chagas disease, both in mice and humans $(111,114,115)$. In keeping with these data is the fact that the release of immature thymocytes from TNC is enhanced after in vivo or in vitro T. cruzi infection (116). Considering that immature DP T cells abnormally released from the thymus have an activated phenotype (114), it is possible that thymocyte migration disturbances could be partially responsible for the tissue lesions observed in the pathophysiology of the disease. Interestingly, an enhanced deposition of LM is observed in the thymus of infected mice, as well as an increased expression of VLA- 6 on both immature and mature thymocytes and of LM production by TEC $(111,117)$. Nevertheless, whether LM-mediated interactions play a role in the export of immature thymocytes is an issue to be determined. In any case, it does not seem to be dependent on the rise of circulating GC hormones seen in the acute infection (115, $118,119)$, since in vivo GC treatment in normal mice does not induce export of these immature thymocytes (111).

The thymus is also a target organ in Plasmodium berguei infection, with induction of organ atrophy, apoptosis-induced death of DP thymocytes, enhanced chemokine (CXCL12) and ECM contents (LM and FN), and modulation of ECM and chemokine receptor expression on thymocytes (120). Thymocytes from infected animals express lower amounts of VLA-6, mainly the immature DP ones. Conversely, the expression of chemokine receptors is augmented when comparing to non-infected animals. In this case, DP cells, which express lower amounts of VLA-6, migrate less through LM, while mature CD4 and CD8 SP cells migrate more. When combining LM with chemokines, it was observed that LM enhanced CXCL12 and CCL25-induced migration of mature thymocytes from infected mice, suggesting that alterations in LM and chemokine expression, as well as their respective receptors, can modulate 
thymic function and export of mature lymphocytes during $P$. berguei infection.

Although the results are clear, it is important to have in mind that these functional studies have been conducted using mouse LM-111, and we do not know whether similar migratory responses occur toward other LM isoforms, an issue that is worthy to be investigated.

In a second vein, it should be pointed out that the thymus is a target organ in several viral, bacterial, and parasitic diseases [reviewed by Nunes-Alves et al. (121) and Savino (122)], and studies should be performed in various human and animal models of disease in order to define if the alterations described above are specific to given infectious agents, or rather universal.

\section{Type 1 Diabetes}

The non-obese diabetic (NOD) mouse spontaneously develops type 1 autoimmune diabetes, which is mediated by T-celldependent destruction of pancreatic insulin-producing beta-cells (123). Studies in prediabetic animals revealed that the thymus of NOD mice present several alterations, including a higher LM deposition and the formation of giant PVS filled with LM (intermingled with other basement membrane proteins, such as type IV collagen and FN) and mature thymocytes that accumulate within the organ $(18,124-126)$.

Unfortunately, these immunolocalization studies have been conducted using anti-LM polyclonal reagents, and it remains to be determined if the intra-PVS LM network is formed by a particular LM isoform.

Thymocytes from NOD mice present lower levels of membrane VLA-5 (a FN receptor), but a higher VLA-6 expression when comparing with $\mathrm{C} 57 \mathrm{BL} / 6$ mice $(18,126)$. This higher expression was accompanied by enhanced LM-driven migration and LM-driven upregulation of CXCL12-induced migration of thymocytes. Interestingly, an opposite effect was observed with FN. The defect in VLA-5 expression was accompanied by a diminished CXCL12-induced migration through FN-coated membranes (18). As thymocytes accumulate in thymic PVS, it is conceivable that, although thymocytes interacting with LM are able to migrate toward chemokines, a preponderant role is played by the aberrant VLA-5 expression and the consequent decreased FN-driven migration capacity of NOD thymocytes. All together, these findings indicate that, in the NOD mouse thymus, different individual vectors, such as those mediated by FN and LM interactions, regulate positively or negatively the resulting migratory response.

Another relevant point to have in mind is that, as mentioned before, these studies have been performed in prediabetic NOD mice, and it has not been defined if the same changes remain after overt diabetes has been settled in these animals.

In this respect, we have recently evaluated normal mice turned diabetic after a single injection of alloxan, a drug known to destroy insulin-producing cells in the pancreas. The distribution and density of LM in thymuses from diabetic animal group (3 days following alloxan injection) was increased in both cortical and medullary regions of the thymic lobules, as compared to controls. By contrast, there was a decrease in VLA-6 expression in developing thymocytes from diabetic mice, although the migratory response of these thymocytes to LM was not altered, in the presence or absence of CXCL12 (127).

Overall, the data summarized above indicate that LM receptor expression as well as migratory responsiveness to LM may change before versus after overt diabetes. Nevertheless, this hypothesis should be taken with precaution since the experimental animals used were different.

Lastly, whether or not thymocytes from NOD or alloxantreated animals respond similarly to LM isoforms other than LM-111 has not been investigated so far, and is obviously a missing point that deserves to be investigated.

\section{CONCLUDING REMARKS}

Cumulative data summarized herein clearly show that LMs and their integrin-type receptors are constitutively expressed in the thymus, and that LM-mediated interactions are comprised within the complex ligand/receptor molecular network that ultimately guide thymocytes in a fine-tuned oriented movement of developing thymocytes throughout the thymic lobules. If we use the multivectorial concept of intrathymic T-cell migration, it is clear that the LM-mediated interactions can be considered one vector (or group of vectors). Furthermore, this vector can be controlled by other vectors (such as those represented by semaphorin/NRP and Eph/Ephrin interactions) and can also influence other vectors, as that mediated by CXCL12/CXCR4, and possibly many others.

It should be noted however that several issues should be elucidated. For instance, if there is a natural mutant $d y / d y$ mouse, where thymocyte development is severely affected, studies on the thymus of genetically engineered animals, already produced by either conventional or conditional knockout strategies for other LM or LM receptor chains, have not been conducted so far. Such studies certainly represent an important open avenue for future research. Similarly, although we have silenced the ITGA6 gene in human-cultured TEC by specific small interference RNA and did find modulation of a large number of cell migration-related genes and a downregulatory effect upon TEC adhesion (72), this strategy has not been used in vivo, after direct injection within the thymus.

Another aspect deserving to be experimentally approached is whether or not there is functional redundancy of distinct LM isoforms in terms of the effects upon thymocyte migration.

Developing these issues will provide important clues for better define the precise role of LM-mediated interactions upon intrathymic T-cell migration and development in health and disease.

\section{ACKNOWLEDGMENTS}

This work was financially supported by grants from $\mathrm{CNPq}$, Capes, Faperj, and Fiocruz (Brazil), and Focem (Mercosur). 


\section{REFERENCES}

1. Boehm T. Thymus development and function. Curr Opin Immunol (2008) 20:178-84. doi:10.1016/j.coi.2008.03.001

2. Miller JFAP. Revisiting thymus function. Front Immunol (2014) 5:411. doi:10.3389/fimmu.2014.00411

3. Cowan JE, Jenkinson WE, Anderson G. Thymus medulla fosters generation of natural Treg cells, invariant $\gamma \delta$ T cells, and invariant NKT cells: what we learn from intrathymic migration. Eur J Immunol (2015) 45:652-60. doi:10.1002/eji.201445108

4. Petrie HT, Zúñiga-Pflücker JC. Zoned out: functional mapping of stromal signaling microenvironments in the thymus. Annu Rev Immunol (2007) 25:649-79. doi:10.1146/annurev.immunol.23.021704.115715

5. Ciofani M, Zúñiga-Pflücker JC. The thymus as an inductive site for T lymphopoiesis. Annu Rev Cell Dev Biol (2007) 23:463-93. doi:10.1146/annurev. cellbio.23.090506.123547

6. Shah DK, Zúñiga-Pflücker JC. An overview of the intrathymic intricacies of $\mathrm{T}$ cell development. J Immunol (2014) 192:4017-23. doi:10.4049/ jimmunol.1302259

7. Halkias J, Melichar HJ, Taylor KT, Robey EA. Tracking migration during human T cell development. Cell Mol Life Sci (2014) 71(16):3101-17. doi:10.1007/s00018-014-1607-2

8. Kreslavsky T, Gleimer M, Miyazaki M, Choi Y, Gagnon E, Murre C, et al. $\beta$-selection-induced proliferation is required for $\alpha \beta \mathrm{T}$ cell differentiation. Immunity (2012) 37:840-53. doi:10.1016/j.immuni.2012.08.020

9. Dudley EC, Petrie HT, Shah LM, Owen MJ, Hayday AC. T cell receptor beta chain gene rearrangement and selection during thymocyte development in adult mice. Immunity (1994) 1:83-93. doi:10.1016/1074-7613(94)90102-3

10. Hogquist $\mathrm{K}$. T cell receptor antagonist peptides induce positive selection. Cell (1994) 76:17-27. doi:10.1016/0092-8674(94)90169-4

11. Mick VE, Starr TK, McCaughtry TM, McNeil LK, Hogquist KA. The regulated expression of a diverse set of genes during thymocyte positive selection in vivo. J Immunol (2004) 173:5434-44. doi:10.4049/jimmunol.173.9.5434

12. Klein L, Kyewski B, Allen PM, Hogquist KA. Positive and negative selection of the T cell repertoire: what thymocytes see (and don't see). Nat Rev Immunol (2014) 14:377-91. doi:10.1038/nri3667

13. Yui MA, Rothenberg EV. Developmental gene networks: a triathlon on the course to T cell identity. Nat Rev Immunol (2014) 14:529-45. doi:10.1038/ nri3702

14. Singer A, Adoro S, Park J. Lineage fate and intense debate: myths, models and mechanisms of CD4- versus CD8-lineage choice. Nat Rev Immunol (2009) 8:788-801. doi:10.1038/nri2416.Lineage

15. Anderson G, Takahama Y. Thymic epithelial cells: working class heroes for $\mathrm{T}$ cell development and repertoire selection. Trends Immunol (2012) 33:256-63. doi:10.1016/j.it.2012.03.005

16. Savino W, Mendes-Da-Cruz DA, Silva JS, Dardenne M, Cotta-De-Almeida V. Intrathymic T-cell migration: a combinatorial interplay of extracellular matrix and chemokines? Trends Immunol (2002) 23:305-13. doi:10.1016/ S1471-4906(02)02224-X

17. Takahama Y. Journey through the thymus: stromal guides for T-cell development and selection. Nat Rev Immunol (2006) 6:127-35. doi:10.1038/nri1781

18. Mendes-da-Cruz DA, Smaniotto S, Keller AC, Dardenne M, Savino W. Multivectorial abnormal cell migration in the NOD mouse thymus. J Immunol (2008) 180:4639-47. doi:10.4049/jimmunol.180.7.4639

19. Savino W, Mendes-Da-Cruz DA, Smaniotto S, Silva-Monteiro E, Villa-Verde DMS. Molecular mechanisms governing thymocyte migration: combined role of chemokines and extracellular matrix. J Leukoc Biol (2004) 75:951-61. doi:10.1189/jlb.1003455

20. Mathis D, Benoist C. Annu Rev Immunol (2009) 27:287-312. doi:10.1146/ annurev.immunol.25.022106.141532

21. Ucar O, Rattay K. Promiscuous gene expression in the thymus: a matter of epigenetics, miRNA, and more? Front Immunol (2015) 6:93. doi:10.3389/ fimmu.2015.00093

22. Aumailley M, Bruckner-Tuderman L, Carter WG, Deutzmann R, Edgar D, Ekblom P, et al. A simplified laminin nomenclature. Matrix Biol (2005) 24:326-32. doi:10.1016/j.matbio.2005.05.006

23. Aumailley M. The laminin family. Cell Adh Migr (2013) 7:48-55. doi:10.4161/ cam. 22826
24. Hohenester E, Yurchenco PD. Laminins in basement membrane assembly. Cell Adh Migr (2013) 7:56-63. doi:10.4161/cam.21831

25. Belkin AM, Stepp MA. Integrins as receptors for laminins. Microsc Res Tech (2000) 51:280-301. doi:10.1002/1097-0029(20001101)51:3<280::AID-JEMT7>3.0.CO;2-O

26. Nishiuchi R, Takagi J, Hayashi M, Ido H, Yagi Y, Sanzen N, et al. Ligandbinding specificities of laminin-binding integrins: a comprehensive survey of laminin-integrin interactions using recombinant $\alpha 3 \beta 1, \alpha 6 \beta 1, \alpha 7 \beta 1$ and $\alpha 6 \beta 4$ integrins. Matrix Biol (2006) 25:189-97. doi:10.1016/j.matbio.2005.12.001

27. Ido H, Ito S, Taniguchi Y, Hayashi M, Sato-Nishiuchi R, Sanzen N, et al. Laminin isoforms containing the gamma3 chain are unable to bind to integrins due to the absence of the glutamic acid residue conserved in the C-terminal regions of the gamma1 and gamma2 chains. J Biol Chem (2008) 283:28149-57. doi:10.1074/jbc.M803553200

28. Golbert DCF, Linhares-Lacerda L, Almeida LG, Correa-de-Santana E, de Oliveira AR, Mundstein AS, et al. Laminin database: a tool to retrieve high-throughput and curated data for studies on laminins. Nucleic Acids Res (2011) 39:D320-3. doi:10.1093/nar/gkq1055

29. Kutleša S, Siler U, Speiser A, Wessels JT, Virtanen I, Rousselle P, et al. Developmentally regulated interactions of human thymocytes with different laminin isoforms. Immunology (2002) 105:407-18. doi:10.1046/j.1365-2567.2002.01384.x

30. Chang AC, Wadsworth S, Coligan JE. Expression of merosin in the thymus and its interaction with thymocytes. J Immunol (1993) 151:1789-801.

31. Chang AC, Salomon DR, Wadsworth S, Hong MJ, Mojcik CF, Otto S, et al. $\alpha 3 \beta 1$ and $\alpha 6 \beta 1$ integrins mediate laminin/merosin binding and function as costimulatory molecules for human thymocyte proliferation. J Immunol (1995) 154:500-10.

32. Mori K, Itoi M, Tsukamoto N, Kubo H, Amagai T. The perivascular space as a path of hematopoietic progenitor cells and mature T cells between the blood circulation and the thymic parenchyma. Int Immunol (2007) 19:745-53. doi:10.1093/intimm/dxm041

33. Doliana R, Bellina I, Bucciotti F, Mongiat M, Perris R, Colombatti A. The human $\alpha 3 \mathrm{~b}$ is a "full-sized" laminin chain variant with a more widespread tissue expression than the truncated $\alpha 3$ a. FEBS Lett (1997) 417:65-70. doi:10.1016/S0014-5793(97)01251-9

34. Kikkawa Y, Sanzen N, Fujiwara H, Sonnenberg A, Sekiguchi K. Integrin binding specificity of laminin-10/11: laminin-10/11 are recognized by $\alpha 3 \beta 1$, $\alpha 6 \beta 1$ and $\alpha 6 \beta 4$ integrins. J Cell Sci (2000) 113(Pt 5):869-76.

35. Siler U, Rousselle P, Müller CA, Klein G. Laminin gamma2 chain as a stromal cell marker of the human bone marrow microenvironment. Br J Haematol (2002) 119:212-20. doi:10.1046/j.1365-2141.2002.03800.x

36. Ishikawa T, Wondimu Z, Oikawa Y, Ingerpuu S, Virtanen I, Patarroyo M. Monoclonal antibodies to human laminin $\alpha 4$ chain globular domain inhibit tumor cell adhesion and migration on laminins 411 and 421 , and binding of $\alpha 6 \beta 1$ integrin and MCAM to $\alpha 4$-laminins. Matrix Biol (2014) 36:5-14 doi:10.1016/j.matbio.2014.03.003

37. Golbert DCF, Santana-van-Vliet E, Mundstein AS, Calfo V, Savino W, de Vasconcelos ATR. Laminin-database v.2.0: an update on laminins in health and neuromuscular disorders. Nucleic Acids Res (2014) 42:D426-9. doi:10.1093/nar/gkt901

38. Spessotto P, Gronkowska A, Deutzmann R, Perris R, Colombatti A. Preferential locomotion of leukemic cells towards laminin isoforms 8 and 10. Matrix Biol (2003) 22:351-61. doi:10.1016/S0945-053X(03)00050-7

39. Gawlik KI, Li J-Y, Petersén A, Durbeej M. Laminin $\alpha 1$ chain improves laminin $\alpha 2$ chain deficient peripheral neuropathy. Hum Mol Genet (2006) 15:2690-700. doi:10.1093/hmg/ddl201

40. Hirosaki T, Tsubota Y, Kariya Y, Moriyama K, Mizushima H, Miyazaki K. Laminin-6 is activated by proteolytic processing and regulates cellular adhesion and migration differently from laminin-5. J Biol Chem (2002) 277:49287-95. doi:10.1074/jbc.M111096200

41. Lowell C, Mayadas T. Overview-studing integrins in vivo. Methods Mol Biol (2012) 757:369-97. doi:10.1007/978-1-61779-166-6

42. Domogatskaya A, Rodin S, Tryggvason K. Functional diversity of laminins. Annu Rev Cell Dev Biol (2012) 28:523-53. doi:10.1146/ annurev-cellbio-101011-155750

43. Colognato H, Galvin J, Wang Z, Relucio J, Nguyen T, Harrison D, et al. Identification of dystroglycan as a second laminin receptor in 
oligodendrocytes, with a role in myelination. Development (2007) 134:172336. doi:10.1242/dev.02819

44. Kühn K, Eble J. The structural bases of integrin-ligand interactions. Trends Cell Biol (1994) 4:256-61. doi:10.1016/0962-8924(94)90124-4

45. Mercurio AM. Laminin receptors: achieving specificity through cooperation. Trends Cell Biol (1995) 5:419-23. doi:10.1016/S0962-8924(00)89100-X

46. Mizushima H, Takamura H, Miyagi Y, Kikkawa Y, Yamanaka N, Yasumitsu $\mathrm{H}$, et al. Identification of integrin-dependent and -independent cell adhesion domains in $\mathrm{COOH}$-terminal globular region of laminin-5 $\alpha 3$ chain. Cell Growth Differ (1997) 8:979-87.

47. Nomizu M, Kim WH, Yamamura K, Utani A, Song SY, Otaka A, et al. Identification of cell binding sites in the laminin $\alpha 1$ chain carboxyl-terminal globular domain by systematic screening of synthetic peptides. J Biol Chem (1995) 270:20583-90. doi:10.1074/jbc.270.35.20583

48. Wondimu Z, Geberhiwot T, Ingerpuu S, Juronen E, Xie X, Lindbom L, et al. An endothelial laminin isoform, laminin $8(\alpha 4 \beta 1 \gamma 1)$, is secreted by blood neutrophils, promotes neutrophil migration and extravasation, and protects neutrophils from apoptosis. Blood (2004) 104:1859-66. doi:10.1182/ blood-2004-01-0396

49. Durbeej M. Laminins. Cell Tissue Res (2010) 339:259-68. doi:10.1007/ s00441-009-0838-2

50. Rose DM, Alon R, Ginsberg MH. Integrin modulation and signaling in leukocyte adhesion and migration. Immunol Rev (2007) 218:126-34. doi:10.1111/j.1600-065X.2007.00536.x

51. Luo B-H, Carman CV, Springer TA. Structural basis of integrin regulation and signaling. Annu Rev Immunol (2007) 25:619-47. doi:10.1146/annurev. immunol.25.022106.141618

52. Lannes-Vieira J, Dardenne M, Savino W. Extracellular matrix components of the mouse thymus: ontogenetic studies and modulation by glucocorticois hormones. J Histochem Cytochem (1991) 39:1539-46. doi:10.1177/39.11.1918928

53. Berrih S, Savino W, Cohen S. Extracellular matrix of the human thymus: immunofluorescence studies on frozen sections and cultured epithelial cells. J Histochem Cytochem (1985) 33:655-64. doi:10.1177/33.7.3891843

54. Bofill M, Janossy G, Willcox N, Chilosi M, Trejdosiewicz LK, Newsom-Davis J. Microenvironments in the normal thymus and the thymus in myasthenia gravis. Am J Pathol (1985) 119:462-73.

55. Ayres-Martins S, Lannes-Vieira J, Farias-De-Oliveira DA, Brito JM, VillaVerde DMS, Savino W. Phagocytic cells of the thymic reticulum interact with thymocytes via extracellular matrix ligands and receptors. Cell Immunol (2004) 229:21-30. doi:10.1016/j.cellimm.2004.06.002

56. Vivinus-Nebot M, Ticchioni M, Mary F, Hofman P, Quaranta V, Rousselle P, et al. Laminin 5 in the human thymus: control of T cell proliferation via $\alpha 6 \beta 4$ integrins. J Cell Biol (1999) 144:563-74. doi:10.1083/jcb.144.3.563

57. Ocampo JSP, Brito JMD, Corrêa-de-Santana E, Borojevic R, Villa-Verde DMS, Savino W. Laminin-211 controls thymocyte-thymic epithelial cell interactions. Cell Immunol (2008) 254:1-9. doi:10.1016/j.cellimm.2008.06.005

58. Timpl R. Molecular aspects of basement membrane structure. Prog Clin Biol Res (1985) 171:63-74.

59. Smyth N, Vatansever HS, Murray P, Meyer M, Frie C, Paulsson M, et al. Absence of basement membranes after targeting the LAMC1 gene results in embryonic lethality due to failure of endoderm differentiation. J Cell Biol (1999) 144:151-60. doi:10.1083/jcb.144.1.151

60. Murray P, Edgar D. Regulation of programmed cell death by basement membranes in embryonic development. J Cell Biol (2000) 150:1215-21. doi:10.1083/jcb.150.5.1215

61. Falk M, Ferletta M, Forsberg E, Ekblom P. Restricted distribution of laminin $\alpha 1$ chain in normal adult mouse tissues. Matrix Biol (1999) 18:557-68. doi:10.1016/S0945-053X(99)00047-5

62. Virtanen I, Gullberg D, Rissanen J, Kivilaakso E, Kiviluoto T, Laitinen LA, et al. Laminin alpha1-chain shows a restricted distribution in epithelial basement membranes of fetal and adult human tissues. Exp Cell Res (2000) 257:298-309. doi:10.1006/excr.2000.4883

63. Lannes-Vieira J, Chammas R, Villa-Verde DM, Vannier-dos-Santos MA, Mello-Coelho V, de Souza SJ, et al. Extracellular matrix components of the mouse thymic microenvironment. III. Thymic epithelial cells express the VLA6 complex that is involved in laminin-mediated interactions with thymocytes. Int Immunol (1993) 5(11):1421-30.
64. Holmberg J, Durbeej M. Laminin-211 in skeletal muscle function. Cell Adh Migr (2013) 7:111-21. doi:10.4161/cam.22618

65. Magner W, Chang A, Owens J, Hong MJ, Brooks A, Coligan JE. Aberrant development of thymocytes in mice lacking laminin-2. Dev Immunol (2000) 7:179-93. doi:10.1155/2000/90943

66. Iwao M, Fukada S, Harada T, Tsujikawa K, Yagita H, Hiramine C, et al. Interaction of merosin (laminin 2) with very late activation antigen-6 is necessary for the survival of CD4+ CD8+ immature thymocytes. Immunology (2000) 99:481-8. doi:10.1046/j.1365-2567.2000.00990.x

67. Nieto-Cerón S, del Campo LFS, Muñoz-Delgado E, Vidal CJ, Campoy FJ. Muscular dystrophy by merosin deficiency decreases acetylcholinesterase activity in thymus of Lama2dy mice. $J$ Neurochem (2005) 95:1035-46. doi:10.1111/j.1471-4159.2005.03433.x

68. Drumea-Mirancea M, Wessels JT, Müller CA, Essl M, Eble JA, Tolosa E, et al. Characterization of a conduit system containing laminin-5 in the human thymus: a potential transport system for small molecules. J Cell Sci (2006) 119:1396-405. doi:10.1242/jcs.02840

69. Kim MG, Lee G, Lee SK, Lolkema M, Yim J, Hong SH, et al. Epithelial cell-specific laminin 5 is required for survival of early thymocytes. J Immunol (2000) 165:192-201. doi:10.4049/jimmunol.165.1.192

70. Yousif LF, Di Russo J, Sorokin L. Laminin isoforms in endothelial and perivascular basement membranes. Cell Adh Migr (2013) 7:101-10. doi:10.4161/ cam. 22680

71. Wadsworth S, Halvorson MJ, Coligan JE. Developmentally regulated expression of the beta 4 integrin on immature mouse thymocytes. J Immunol (1992) 149:421-8.

72. Golbert DCF, Correa-de-Santana E, Ribeiro-Alves M, de Vasconcelos ATR, Savino W. ITGA6 gene silencing by RNA interference modulates the expression of a large number of cell migration-related genes in human thymic epithelial cells. BMC Genomics (2013) 14(Suppl 6):S3. doi:10.1186/1471-2164-14-S6-S3

73. Zutter MM, Santoro SA. Widespread histologic distribution of the alpha 2 beta 1 integrin cell-surface collagen receptor. Am J Pathol (1990) 137:113-20.

74. Karaöz E, Ilgaz C, Erdoğan D, Dağdeviren A. The expression of VLA integrins in the human thymus. Ann Anat (1996) 178:33-40. doi:10.1016/ S0940-9602(96)80009-4

75. Mojcik CF, Salomon DR, Chang AC, Shevach EM. Differential expression of integrins on human thymocyte subpopulations. Blood (1995) 86:4206-17.

76. Villa-Verde DM, Mello-Coelho V, Lagrota-Cândido JM, Chammas R, Savino W. The thymic nurse cell complex: an in vitro model for extracellular matrix-mediated intrathymic T cell migration. Braz J Med Biol Res (1995) 28:907-12.

77. Villa-Verde DM, Lagrota-Candido JM, Vannier-Santos MA, Chammas R, Brentani RR, Savino W. Extracellular matrix components of the mouse thymus microenvironment. IV. Modulation of thymic nurse cells by extracellular matrix ligands and receptors. Eur J Immunol (1994) 24:659-64. doi:10.1002/ eji. 1830240326

78. Lagrota-Cândido JM, Villa-Verde DM, Vanderlei FH, Savino W. Extracellular matrix components of the mouse thymus microenvironment. V. Interferongamma modulates thymic epithelial cell/thymocyte interactions via extracellular matrix ligands and receptors. Cell Immunol (1996) 170:235-44. doi:10.1006/cimm.1996.0157

79. de Mello-Coelho V, Villa-Verde DM, Dardenne M, Savino W. Pituitary hormones modulate cell-cell interactions between thymocytes and thymic epithelial cells. J Neuroimmunol (1997) 76:39-49. doi:10.1016/ S0165-5728(97)00031-3

80. Savino W, Villa-Verde DMS, Mendes-da-Cruz DA, Silva-Monteiro E, Perez AR, Aoki MDP, et al. Cytokines and cell adhesion receptors in the regulation of immunity to Trypanosoma cruzi. Cytokine Growth Factor Rev (2007) 18:107-24. doi:10.1016/j.cytogfr.2007.01.010

81. Mendes-Da-Cruz DA, Stimamiglio MA, Muñoz JJ, Alfaro D, Terra-Granado E, Garcia-Ceca J, et al. Developing T-cell migration: role of semaphorins and ephrins. FASEB J (2012) 26:4390-9. doi:10.1096/fi.11-202952

82. Smaniotto S, De Mello-Coelho V, Villa-Verde DMS, Pléau JM, Postel-Vinay MC, Dardenne M, et al. Growth hormone modulates thymocyte development in vivo through a combined action of laminin and CXC chemokine ligand 12. Endocrinology (2005) 146:3005-17. doi:10.1210/en.2004-0709 
83. Lepelletier Y, Smaniotto S, Hadj-Slimane R, Villa-Verde DMS, Nogueira AC, Dardenne $\mathrm{M}$, et al. Control of human thymocyte migration by neuropilin-1/ semaphorin-3A-mediated interactions. Proc Natl Acad Sci U S A (2007) 104:5545-50. doi:10.1073/pnas.0700705104

84. Mendes-da-Cruz DA, Brignier AC, Asnafi V, Baleydier F, Messias CV, Lepelletier Y, et al. Semaphorin 3F and neuropilin-2 control the migration of human T-cell precursors. PLoS One (2014) 9:e103405. doi:10.1371/journal. pone. 0103405

85. Stimamiglio MA, Jiménez E, Silva-Barbosa SD, Alfaro D, García-Ceca JJ, Muñoz JJ, et al. EphB2-mediated interactions are essential for proper migration of $\mathrm{T}$ cell progenitors during fetal thymus colonization. J Leukoc Biol (2010) 88:483-94. doi:10.1189/jlb.0210079

86. Vivinus-Nebot M, Rousselle P, Breittmayer J-P, Cenciarini C, Berrih-Aknin $\mathrm{S}$, Spong S, et al. Mature human thymocytes migrate on laminin-5 with activation of metalloproteinase-14 and cleavage of CD44. J Immunol (2004) 172:1397-406. doi:10.4049/jimmunol.172.3.1397

87. Gorfu G, Virtanen I, Hukkanen M, Lehto V-P, Rousselle P, Kenne E, et al. Laminin isoforms of lymph nodes and predominant role of alpha5laminin(s) in adhesion and migration of blood lymphocytes. J Leukoc Biol (2008) 84:701-12. doi:10.1189/jlb.0108048

88. Smaniotto S, Mendes-da-Cruz DA, Carvalho-Pinto CE, Araujo LM, Dardenne M, Savino W. Combined role of extracellular matrix and chemokines on peripheral lymphocyte migration in growth hormone transgenic mice. Brain Behav Immun (2010) 24:451-61. doi:10.1016/j.bbi.2009.11.014

89. Linhares-Lacerda L, Ribeiro-Alves M, Nogueira ACMDA, Mendes-da-Cruz DA, Magalhães DA, Dardenne M, et al. RNA interference-mediated knockdown of CD49e ( $\alpha 5$ integrin chain) in human thymic epithelial cells modulates the expression of multiple genes and decreases thymocyte adhesion. BMC Genomics (2010) 11(Suppl 5):S2. doi:10.1186/1471-2164-11-S5-S2

90. Yanagawa Y, Iwabuchi K, Onoé K. Enhancement of stromal cell-derived factor-1alpha-induced chemotaxis for $\mathrm{CD} 4 / 8$ double-positive thymocytes by fibronectin and laminin in mice. Immunology (2001) 104:43-9. doi:10.1046/j.1365-2567.2001.01292.x

91. Smaniotto S, Ribeiro-Carvalho MM, Dardenne M, Savino W, de Mello-Coelho V. Growth hormone stimulates the selective trafficking of thymic CD4+CD8emigrants to peripheral lymphoid organs. Neuroimmunomodulation (2004) 11:299-306. doi:10.1159/000079410

92. Villa-Verde DM, de Mello-Coelho V, Farias-de-Oliveira DA, Dardenne M, Savino W. Pleiotropic influence of triiodothyronine on thymus physiology. Endocrinology (1993) 133:867-75. doi:10.1210/endo.133.2.8344222

93. Ribeiro-Carvalho MM, Farias-de-Oliveira DA, Villa-Verde DMS, Savino W. Triiodothyronine modulates extracellular matrix-mediated interactions between thymocytes and thymic microenvironmental cells. Neuroimmunomodulation (2002) 10:142-52. doi:10.1159/000067175

94. Ribeiro-Carvalho MM, Lima-Quaresma KRF, Mouço T, Carvalho VF, MelloCoelho V, Savino W. Triiodothyronine modulates thymocyte migration. Scand J Immunol (2007) 66:17-25. doi:10.1111/j.1365-3083.2007.01928.x

95. Garcia F, Lepelletier Y, Smaniotto S, Hadj-Slimane R, Dardenne M, Hermine $\mathrm{O}$, et al. Inhibitory effect of semaphorin-3A, a known axon guidance molecule, in the human thymocyte migration induced by CXCL12. J Leukoc Biol (2012) 91:7-13. doi:10.1189/jlb.0111031

96. Castellani V, Rougon G. Control of semaphorin signaling. Curr Opin Neurobiol (2002) 12:532-41. doi:10.1016/S0959-4388(02)00357-4

97. Mendes-da-Cruz DA, Linhares-Lacerda L, Smaniotto S, Dardenne M, Savino W. Semaphorins and neuropilins: new players in the neuroendocrine control of the intrathymic T-cell migration in humans. Exp Physiol (2012) 97:1146-50. doi:10.1113/expphysiol.2011.061515

98. Muñoz JJ, García-Ceca J, Alfaro D, Stimamiglio MA, Cejalvo T, Jiménez E, et al. Organizing the thymus gland. Ann N Y Acad Sci (2009) 1153:14-9. doi:10.1111/j.1749-6632.2008.03965.x

99. Ruiz P, Wiles MV, Imhof BA. Alpha 6 integrins participate in pro-T cell homing to the thymus. Eur J Immunol (1995) 25:2034-41. doi:10.1002/ eji. 1830250735

100. Graner E, Mercadante AF, Zanata SM, Forlenza OV, Cabral AL, Veiga SS, et al. Cellular prion protein binds laminin and mediates neuritogenesis. Brain Res Mol Brain Res (2000) 76:85-92. doi:10.1016/S0169-328X(99)00334-4

101. Coitinho AS, Freitas ARO, Lopes MH, Hajj GNM, Roesler $\mathrm{R}$, Walz $\mathrm{R}$, et al. The interaction between prion protein and laminin modulates memory consolidation. Eur J Neurosci (2006) 24:3255-64. doi:10.1111/j.1460-9568.2006.05156.x

102. Linden R, Martins VR, Prado MAM, Cammarota M, Izquierdo I, Brentani RR. Physiology of the prion protein. Physiol Rev (2008) 88:673-728. doi:10.1152/physrev.00007.2007

103. Beraldo FH, Arantes CP, Santos TG, Machado CF, Roffe M, Hajj GN, et al. Metabotropic glutamate receptors transduce signals for neurite outgrowth after binding of the prion protein to laminin $\gamma 1$ chain. FASEB J (2011) 25:265-79. doi:10.1096/f.10-161653

104. Jouvin-Marche E, Attuil-Audenis V, Aude-Garcia C, Rachidi W, Zabel M, Podevin-Dimster V, et al. Overexpression of cellular prion protein induces an antioxidant environment altering $\mathrm{T}$ cell development in the thymus. J Immunol (2006) 176:3490-7. doi:10.4049/jimmunol.176.6.3490

105. Terra-Granado E, Berbert LR, De Meis J, Nomizo R, Martins VR, Savino $\mathrm{W}$, et al. Is there a role for cellular prion protein in intrathymic $\mathrm{T}$ cell differentiation and migration? Neuroimmunomodulation (2007) 14:213-9. doi:10.1159/000110649

106. Guo XK, Liu YF, Zhou Y, Sun XY, Qian XP, Zhang Y, et al. The expression of netrin-1 in the thymus and its effects on thymocyte adhesion and migration. Clin Dev Immunol (2013) 2013:462152. doi:10.1155/2013/462152

107. Leu S-J, Liu Y, Chen N, Chen C-C, Lam SC-T, Lau LF. Identification of a novel integrin 61 binding site in the angiogenic inducer CCN1 (CYR61). J Biol Chem (2003) 278:33801-8. doi:10.1074/jbc.M305862200

108. Griffith AV, Fallahi M, Nakase H, Gosink M, Young B, Petrie HT. Spatial mapping of thymic stromal microenvironments reveals unique features influencing T lymphoid differentiation. Immunity (2009) 31:999-1009. doi:10.1016/j.immuni.2009.09.024

109. Emre Y, Irla M, Dunand-Sauthier I, Ballet R, Meguenani M, Jemelin S, et al. Thymic epithelial cell expansion through matricellular protein CYR61 boosts progenitor homing and T-cell output. Nat Commun (2013) 4:2842. doi:10.1038/ncomms 3842

110. Leite de Moraes MC, Hontebeyrie-Joskowicz M, Dardenne M, Savino W. Modulation of thymocyte subsets during acute and chronic phases of experimental Trypanosoma cruzi infection. Immunology (1992) 77:95-8.

111. Cotta-de-Almeida V, Bonomo A, Mendes-da-Cruz DA, Riederer I, de Meis J, Ferreira Lima-Quaresma KR, et al. Trypanosoma cruzi infection modulates intrathymic contents of extracellular matrix ligands and receptors and alters thymocyte migration. Eur J Immunol (2003) 33:2439-48. doi:10.1002/ eji. 200323860

112. Mendes-da-Cruz DA, de Meis J, Cotta-de-Almeida V, Savino W. Experimental Trypanosoma cruzi infection alters the shaping of the central and peripheral T-cell repertoire. Microbes Infect (2003) 5:825-32. doi:10.1016/ S1286-4579(03)00156-4

113. Farias-de-Oliveira DA, Villa-Verde DMS, Nunes Panzenhagen PH, Silva dos Santos D, Berbert LR, Savino W, et al. Caspase-8 and caspase-9 mediate thymocyte apoptosis in Trypanosoma cruzi acutely infected mice. J Leukoc Biol (2013) 93:227-34. doi:10.1189/jlb.1211589

114. Morrot A, Terra-Granado E, Pérez AR, Silva-Barbosa SD, Milićević NM, Farias-de-Oliveira DA, et al. Chagasic thymic atrophy does not affect negative selection but results in the export of activated CD4+CD8+ T cells in severe forms of human disease. PLoS Negl Trop Dis (2011) 5:e1268. doi:10.1371/ journal.pntd. 0001268

115. Lepletier A, de Almeida L, Santos L, da Silva Sampaio L, Paredes B, González FB, et al. Early double-negative thymocyte export in Trypanosoma cruzi infection is restricted by sphingosine receptors and associated with human chagas disease. PLoS Negl Trop Dis (2014) 8:e3203. doi:10.1371/journal. pntd.0003203

116. Cotta-de-Almeida V, Bertho AL, Villa-Verde DM, Savino W. Phenotypic and functional alterations of thymic nurse cells following acute Trypanosoma cruzi infection. Clin Immunol Immunopathol (1997) 82:125-32. doi:10.1006/ clin. 1996.4283

117. Farias-de-Oliveira DA, Cotta-de-Almeida V, Villa-Verde DMS, Riederer I, de Meis J, Savino W. Fibronectin modulates thymocyte-thymic epithelial cell interactions following Trypanosoma cruzi infection. Mem Inst Oswaldo Cruz (2013) 108:825-31. doi:10.1590/0074-0276130071

118. Leite de Moraes MC, Hontebeyrie-Joskowicz M, Leboulenger F, Savino W, Dardenne M, Lepault F. Studies on the thymus in Chagas' disease. II. Thymocyte subset fluctuations in Trypanosoma cruzi-infected mice: 
relationship to stress. Scand J Immunol (1991) 33:267-75. doi:10.111 1/j.1365-3083.1991.tb01772.x

119. Corrêa-de-Santana E, Paez-Pereda M, Theodoropoulou M, Kenji Nihei O, Gruebler Y, Bozza M, et al. Hypothalamus-pituitary-adrenal axis during Trypanosoma cruzi acute infection in mice. J Neuroimmunol (2006) 173:12-22. doi:10.1016/j.jneuroim.2005.08.015

120. Gameiro J, Nagib PRA, Andrade CF, Villa-Verde DMS, Silva-Barbosa SD, Savino W, et al. Changes in cell migration-related molecules expressed by thymic microenvironment during experimental Plasmodium berghei infection: consequences on thymocyte development. Immunology (2010) 129:248-56. doi:10.1111/j.1365-2567.2009.03177.x

121. Nunes-Alves C, Nobrega C, Behar SM, Correia-Neves M. Tolerance has its limits: how the thymus copes with infection. Trends Immunol (2013) 34:502-10. doi:10.1016/j.it.2013.06.004

122. Savino $\mathrm{W}$. The thymus is a common target organ in infectious diseases. PLoS Pathog (2006) 2:e62. doi:10.1371/journal.ppat.0020062

123. Reed JC, Herold KC. Thinking bedside at the bench: the NOD mouse model of T1DM. Nat Rev Endocrinol (2015) 11:308-14. doi:10.1038/ nrendo.2014.236

124. Savino W, Boitard C, Bach JF, Dardenne M. Studies on the thymus in nonobese diabetic mouse. I. Changes in the microenvironmental compartments. Lab Invest (1991) 64:405-17.

125. Savino W, Carnaud C, Luan JJ, Bach JF, Dardenne M. Characterization of the extracellular matrix-containing giant perivascular spaces in the NOD mouse thymus. Diabetes (1993) 42:134-40. doi:10.2337/diabetes.42.1.134
126. Cotta-de-Almeida V, Villa-Verde DMS, Lepault F, Pléau J-M, Dardenne M, Savino W. Imp migration of NOD mouse thymocytes: a fibronectin receptor-related defect. Eur J Immunol (2004) 34:1578-87. doi:10.1002/ eji.200324765

127. Nagib PRA, Gameiro J, Guilherme Stivanin-Silva L, Sueli Parreira de Arruda M, Maria Serra Villa-Verde D, Savino W, et al. Thymic microenvironmental alterations in experimentally induced diabetes. Immunobiology (2010) 215:971-9. doi:10.1016/j.imbio.2010.02.001

128. Savino W, Dardenne M. Neuroendocrine control of thymus physiology. Endocr Rev (2000) 21:412-43. doi:10.1210/edrv.21.4.0402

129. Savino W, Dardenne M, Velloso LA, Dayse Silva-Barbosa S. The thymus is a common target in malnutrition and infection. Br J Nutr (2007) 98(Suppl 1):S11-6. doi:10.1017/S0007114507832880

Conflict of Interest Statement: The authors declare that the research was conducted in the absence of any commercial or financial relationships that could be construed as a potential conflict of interest.

Copyright (c) 2015 Savino, Mendes-da-Cruz, Golbert, Riederer and Cotta-deAlmeida. This is an open-access article distributed under the terms of the Creative Commons Attribution License (CC BY). The use, distribution or reproduction in other forums is permitted, provided the original author(s) or licensor are credited and that the original publication in this journal is cited, in accordance with accepted academic practice. No use, distribution or reproduction is permitted which does not comply with these terms. 